\title{
Analisis Pengaruh Risiko Perbankan terhadap Laba Bersih bank Syariah
}

\author{
Lydia Octaviani \\ Universitas Singaperbangsa Karawang \\ 1810631030126@student.unsika.ac.id
}

\section{Gusganda Suria Manda}

Universitas Singaperbangsa Karawang

Gusganda.suriamanda@fe.unsika.ac.id

\begin{abstract}
Abstrak Bank selalu menghadapi risiko perbankan yang sangat kompleks dalam setiap menjalankan segala kegiatan usahanya. Oleh karena itu, bank harus menganalisis seluruh risiko yang harus dihadapi oleh perbankan langsung maupun tidak yang dapat mempengaruhi keberlangsungan kegiatan perbankan, sehingga risiko tersebut tidak mempengaruhi keuntungan perusahaan. Penelitian ini diharapkan dapat berguna untuk memberikan jawaban dari hasil analisis apakah risiko (yaitu risiko kredit yang dihitung dengan NPF, risiko operasional yang dihitung dengan BOPO dan risiko likuiditas yang dihitung dengan FDR) akan mempengaruhi laba bersih bank syariah yang terdapat di Otoritas Jasa Keuangan (OJK) pada tahun 2015-2019. Analisis kuantitatif dengan mempergunakan aplikasi SPSS 25 untuk melakukan pengujian data yaitu dengan menganalisis uji asumsi klasik, koefisien determinasi, dan Uji-F, serta uji-t. Jenis data sekunder yang diperoleh pada website tiaptiap perbankan memuat data penelitian yang digunakan yaitu data NPF, BOPO, dan FDR, serta laba bersih bank syariah dari tahun 2015 hingga 2019. Analisis data yang telah dilakukan menjelaskan bahwa menurut Uji-F Hasilnya, variabel NPF, BOPO, dan FDR memiliki pengaruh terhadap variabel Laba Bersih secara simultan. Pada hasil Uji-T menyatakan hanya variabel FDR yang secara parsial tidak mempengaruhi variabel Laba Bersih. Di sisi lain, variabel lain (yaitu, NPF dan BOPO) secara parsial akan mempengaruhi variabel dependen (yaitu, Laba Bersih).
\end{abstract}

Kata Kunci $\quad N P F, B O P O, F D R$, dan Laba Bersih

\section{PENDAHULUAN}

Bank Syariah termasuk dalam lembaga keuangan yang bergerak pada bidang Syariah. Pada saat menjalankan kegiatan usahanya, bank terus menghadapi berbagai risiko perbankan yang sangat kompleks. Beberapa risiko perbankan yaitu Resiko kredit, Risiko Likuiditas, dan Risiko operasional. Untuk mengatasi masalah tersebut, bank harus menganalisis seluruh risiko bank yang dapat mempengaruhi kegiatan usahanya secara langsung maupun tidak. Bank harus mengelola risiko tersebut tanpa mengurangi tujuan 
yang ingin dicapai bank (OJK, 2016). Manajemen risiko yang baik dan tepat dapat menciptakan keuntungan bagi bank (Tasriani, 2015).

Laba adalah bagian dari laporan laba rugi dan dianggap sebagai bagian terpenting dari laporan keuangan. Laba merupakan keuntungan yang diperoleh bank dengan mengukur laba sebelum pajak dan beban pajak. Laba dapat menggambarkan keberhasilan manajemen dan berbagai departemen perusahaan dalam menjalankan aktivitas dan usahanya (Nursya'adah, 2020).

Dalam penelitian yang bertajuk "Analisis Efisiensi Bopo Laba Bersih BPO" yang dilakukan oleh Supeno, diketahui bahwa BOPO akan berpengaruh terhadap laba bersih BPR (Supeno, 2019). Penelitian Sunhayati et al. Al. (2020) menunjukkan bahwa kredit macet tidak berdampak parsial terhadap laba bersih, dan kredit macet dan laba bersih industri perbankan BUMN tidak akan terjadi pada saat yang bersamaan. Saiful Azis (2016) mengemukakan dalam penelitiannya bahwa FDR tidak memiliki adanya pengaruh signifikan pada laba bersih Bank Syariah.

Berdasarkan hal tersebut, peneliti tertarik untuk menemukan apakah risiko perbankan yang berada dalam penelitian ini secara parsial maupun simultan akan mempengaruhi laba bersih dari bank syariah yang berada di Otoritas Jasa Keuangan dari tahun 2015 hingga 2019. Risiko perbankan yang diteliti antara lain risiko kredit yang dihitung dengan $\mathrm{NPF}$, risiko operasional yang dihitung oleh BOPO, dan risiko likuiditas FDR.

\section{LANDASAN TEORI}

\section{Non-Performing Financing (NPF)}

NPF mengacu pada pembiayaan bermasalah yang terjadi terhadap total pembiayaan yang diberikan oleh bank syariah. Menurut Bank Indonesia kredit yang tidak lancar, diragukan dan macet merupakan pembiayaan bermasalah (Wardiantika, 2014). NPF dapat dipergunakan untuk mengevaluasi kinerja dari bank syariah. Karena volatilitasnya, bank harus selalu memperhatikan rasio NPF saat ini (Purbaningsih dan Fatimah, 2014). Menurut Bank Indonesia, rasio NPF bank syariah yang sehat dapat digolongkan sebagai bank dengan rasio NPF kurang dari 5\% (<5\%). Perhitungan NPF dilakukan untuk melihat kisaran pembiayaan yang bermasalah yang harus dihadapi bank. NPF yang berlebihan akan berdampak pada berkurangnya keuntungan bagi bank syariah. NPF yang terlalu tinggi juga berarti bank syariah kurang profesional dalam mengelola keuangan. Selain itu NPF yang terlalu tinggi juga akan mempengaruhi profitabilitas bank (Purbaningsih dan Fatimah, 2014, Riyadi dan Yulianto, 2014). Bank harus selalu memperhatikan risiko NPF karena dapat menimbulkan dampak yang merugikan, seperti berkurangnya modal bank, kerugian bank, dan dampak lainnya (Rofi'ah dan A'yun, 2019). Salah satu faktor yang dapat menyebabkan pembiayaan bermasalah adalah kreditur tidak mengembalikan dana debitur (Rahman dan Safitrie, 2018).

\section{Beban Operasional dan Pendapatan Operasional (BOPO)}

Menurut Malayu (2018: 101), BOPO merupakan sebuah rasio bank yang digunakan untuk membandingkan beban operasional dengan pendapatan operasional bank yang didapat dalam suatu periode. Rasio ini dapat dipergunakan dalam melakukan pengukuran kemampuan perbankan pada saat menjalankan aktivitas bisnisnya (Suciah, 2017). Semakin kecil nilai rasio ini pada bank maka beban operasional yang digunakan oleh bank akan semakin efektif, begitupun sebaliknya (Ningsih, 2013). 


\section{Financing to Deposit Ratio (FDR)}

Rasio dana terhadap simpanan merupakan sebuah rasio yang dapat memperlihatkan kemampuan dari bank untuk menyediakan dan mengarahkan dana yang ada kepada nasabah bank syariah (Riyadi dan Yulianto, 2014). Rasio tersebut dapat menggambarkan tingkat likuiditas bank (Permataningayu dan Mahdaria, 2019). Rasio ini juga dapat menunjukkan tingkat kemampuan bank syariah untuk mengarahkan simpanan yang terkumpul (Suhartatik, 2013).

Rasio standar yang ditetapkan untuk FDR adalah antara 80\% dan 110\% (Suharyani, 2011). Nilai persentase rasio FDR yang diperoleh terlalu tinggi ataupun terlalu rendah dapat menunjukkan bahwa bank secara efektif tidak dapat menghimpun dan mengarahkan dana nasabah untuk mempengaruhi keuntungannya (Riyadi dan Yulianto, 2014). Rasio FDR yang berada dalam batasan yang sudah ditetapkan Bank Indonesia dapat meningkatkan laba bank (Suharyani, 2011).

\section{Laba Bersih}

Laba bersih mengacu pada besarnya keuntungan / penghasilan yang diperoleh dari pemotongan seluruh penghasilan dan seluruh pengeluaran kemudian dikurangi pajak (Fatmawati, 2016, Febrianto dan Widiastuty, 2005). Pendapatan dan beban merupakan elemen yang berhubungan langsung dengan pengukuran laba bersih. Tujuan laba perusahaan adalah untuk pertumbuhan aset yang menguntungkan dan menggambarkan keberhasilan manajemen bank dalam mengelola bank (Nursya'adah, 2020). Bank juga dapat menggunakan laba untuk mengukur nilai yang diberikan kepada investor dalam bentuk dividen (Rispayanto, 2013).

Melalui uraian literatur yang telah dijelaskan sebelumnya, maka kerangka penelitian dapat dibentuk seperti sebagai berikut:

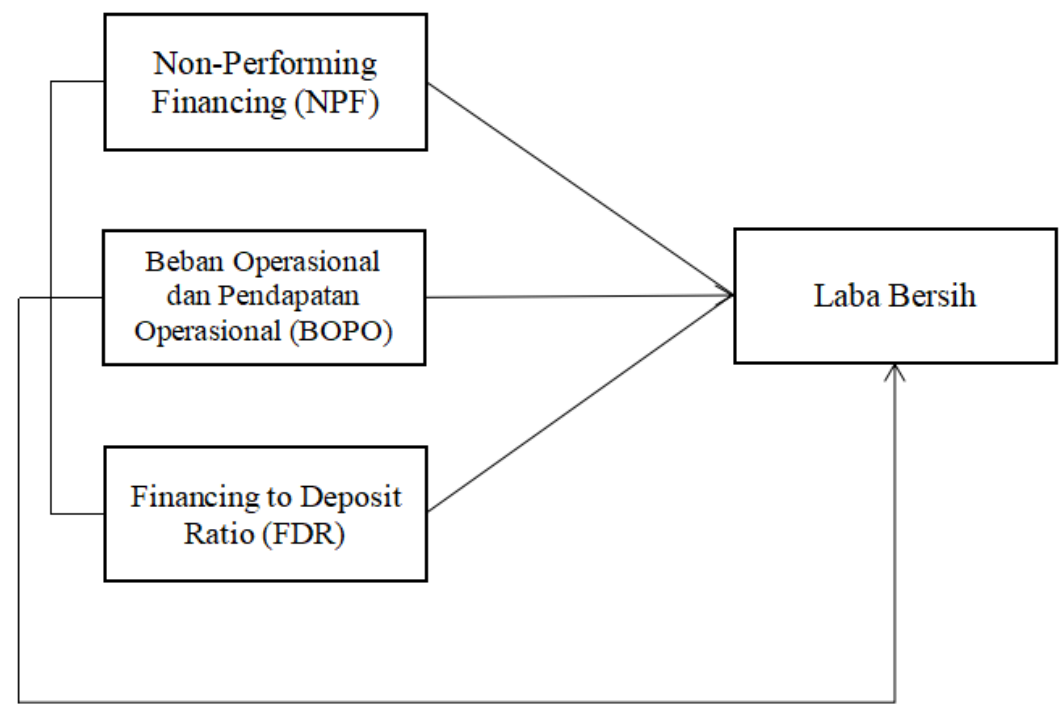

Gambar 2.1. Kerangka Penelitian

\section{METODOLOGI PENELITIAN}

Analisis kuantitatif dengan menggunakan aplikasi SPSS 25 untuk melakukan pengujian data dengan analisis regresi berganda yaitu dengan menganalisis uji asumsi klasik, koefisien determinasi, dan Uji-F, serta uji-t. Jenis data sekunder yang diperoleh melalui 
situs tiap-tiap perbankan memuat data penelitian yang digunakan yaitu data NPF, BOPO, dan FDR, serta laba bersih bank syariah dari tahun 2015 hingga 2019. Variabel yang akan diteliti adalah NPF, BOPO, dan juga FDR sebagai variabel bebas perbankan dan laba bersih sebagai variabel terikatnya.

\section{HASIL PENELITIAN}

\section{Koefisien Determinasi $\left(\mathbf{R}^{2}\right)$}

Uji koefisien determinasi dapat bermanfaat untuk memperlihatkan kemampuan dari variabel-variabel independen penelitian dalam menguraikan gambaran tentang variabel dependennya (Ghozali, 2018).

Tabel 1. Hasil Koefisien Determinasi

\begin{tabular}{|r|c|r|r|}
\hline \multicolumn{4}{|c|}{ Model Summary $^{\mathbf{b}}$} \\
\hline Model & \multicolumn{1}{|c|}{$\mathrm{R}$} & R Square & Durbin-Watson \\
\hline 1 & $.673 \mathrm{a}$ & .453 & .967 \\
\hline
\end{tabular}

Hasil perhitungan pada Model Summary diperoleh nilai R square yang sebesar 0,453 atau 45,3\%. Hasil ini memperlihatkan bahwa hanya 45,3\% variabel dependen (laba bersih) dapat diuraikan oleh ketiga variabel independen (NPF, BOPO, dan FDR). Sebagai perbandingan, 54,7\% variabel dependen dapat diuraikan melalui variabel selain variabel penelitian.

\section{Uji-F}

Uji-F ini dapat dipergunakan untuk melihat secara simultan pengaruh yang dihasilkan antar variabel independen dengan variabel dependennya. Kondisi hasil F-Test yaitu antara lain:

a. Jika hasil signifikan tabel ANOVA $<0,05$ maka hipotesis penelitian dapat diterima. Maksudnya yaitu variabel independen mempengaruhi variabel dependen pada saat yang bersamaan.

b. Jika nilai Fhitung > Ftabel maka hipotesis penelitian dapat diterima. Maksudnya yaitu variabel independen berpengaruh pada variabel dependen pada saat yang bersamaan (Ghozali, 2018).

Tabel 2. Hasil Uji-F

\begin{tabular}{|r|l|c|c|}
\hline \multicolumn{3}{|c|}{ ANOVA $^{\text {a }}$} \\
\hline \multicolumn{1}{|l|}{ Model } & F & Sig. \\
\hline \multirow{2}{*}{1} & Regression & 15.473 & $.000 \mathrm{~b}$ \\
\cline { 2 - 4 } & Residual & & \\
\cline { 2 - 4 } & Total & & \\
\hline
\end{tabular}

Hasil yang didapat diperoleh nilai Fhitung 15,473 > Ftabel 2,77 dan signifikansi nya 0,000 melalui tabel ANOVA. Karena Fhitung > Ftabel dan signifikansi 0,000 < signifikan 
0,005 maka dapat diambil kesimpulan bahwa risiko bank dan laba bersih bank syariah memiliki pengaruh pada waktu yang bersamaan.

\section{Uji-T}

Uji-T ini dapat berguna untuk melihat besarnya pengaruh dari variabel bebas dalam suatu penelitian terhadap variabel terikatnya (Ghozali, 2018).

Tabel 3. Hasil Uji-T

\begin{tabular}{|c|c|c|c|}
\hline \multicolumn{4}{|c|}{ Coefficients $^{\mathrm{a}}$} \\
\hline \multirow[b]{2}{*}{ Model } & $\begin{array}{l}\text { Unstandardized } \\
\text { Coefficients }\end{array}$ & & \\
\hline & B & $\mathrm{t}$ & Sig. \\
\hline 1 (Constant) & 908.630 .886 .540 .380 & 7.113 & 0 \\
\hline NPF & -67.087 .905 .234 .246 & -3.054 & 3 \\
\hline OEOI & -6.123 .863 .584 .098 & -4.648 & 0 \\
\hline FDR & -118.137 .800 & -265 & 792 \\
\hline
\end{tabular}

Dari tabel koefisien terlihat bahwa hanya variabel FDR yang tidak berpengaruh secara parsial terhadap variabel independen di dalam model regresi. Hal ini terlihat dari Sig. untuk NPF 0,003, BOPO 0,000, dan nilai FDR 0,792 > Sig. 0,05. Jadi dapat dikatakan hanya variabel NPF dan BOPO yang berpengaruh secara parsial terhadap laba bersih.

Persamaan matematika yang dibentuk dalam model regresi ini adalah:

Laba bersih $=908.630 .886 .540,380-67.087 .905 .234,246$ X1 - 6.123.863.584,098 X2 $118.137,800 \mathrm{X} 3+\mathrm{e}$

Penjelasan dalam persamaan matematis dalam model regresi ini yaitu:

a. Hasil perhitungan menghasilkan konstanta sebesar 908.630.886.540,380. Hasil tersebut dapat diartikan jika variabel penelitian ini dianggap konstan, maka rata-rata laba bersih yaitu 908.630.886.540,380.

b. Hasil perhitungan menghasilkan koefisien regresi dari NPF sebesar 67.087.905.234,246. Hasil ini berarti bahwa setiap penambahan unit Risiko Kredit yang dihitung dengan menggunakan NPF akan menyebabkan penurunan Laba Bersih sebesar -67.087.905.234.246.

c. Hasil perhitungan menghasilkan koefisien regresi dari BOPO sebesar 6.123.863.584.098. Hasil ini berarti apabila penambahan unit dalam Risiko Operasional dihitung dengan menggunakan BOPO, maka akan menyebabkan Laba Bersih menurun sebesar -6.123.863.584.098.

d. Hasil perhitungan menghasilkan koefisien regresi FDR sebesar-118.137.800. Hal ini berarti apabila penambahan unit dalam Risiko Likuiditas dihitung dengan menggunakan FDR maka akan menyebabkan penurunan Laba Bersih sebesar 118.137.800. 


\section{Uji Asumsi Klasik}

\section{a. Uji Multikolinieritas}

Pengujian ini berguna untuk melihat adanya korelasi antara model regresi penelitian dan variabel bebas yang diteliti. Model regresi yang baik harus independen dari variabel independen yang diteliti.

Nilai VIF dan toleransi pada tabel koefisien dapat dilihat untuk menentukan penelitian multikolinieritas. Jika hasil nilai VIF $\geq 10$ artinya bahwa terjadi multikolinieritas dalam model regresi. Jika nilai toleransi $\leq 0,10$ berarti dalam model regresi terjadi multikolinearitas (Ghozali, 2018).

Tabel 4. Hasil Uji Multikolinieritas

\begin{tabular}{|c|l|r|c|}
\hline \multicolumn{3}{|c|}{ Coefficientsa } \\
\hline \multirow{2}{*}{ Model } & \multicolumn{2}{c|}{ Collinearity Statistics } \\
\cline { 2 - 4 } & Tolerance & VIF \\
\hline \multirow{4}{*}{1} & (Constant) & & \\
\cline { 2 - 4 } & NPF & 819 & 1.221 \\
\cline { 2 - 4 } & OEOI & 831 & 1.203 \\
\cline { 2 - 4 } & FDR & 824 & 1.214 \\
\hline
\end{tabular}

Berdasarkan perhitungan tersebut, nilai toleransi variabel independen lebih dari dari 0,10 . Hasil penghitungan nilai VIF memperlihatkan bahwa nilai variabel independen kurang dari 10. Nilai tersebut dapat berarti bahwa tidak terjadi adanya multikolinieritas diantara variabel bebas dengan model regresi.

\section{b. Uji Autokorelasi}

Uji ini berfungsi sebagai alat untuk memeriksa model regresi linier apakah memiliki korelasi di antara periode kesalahan t dan periode kesalahan t-1 (Ghozali, 2018).

Tabel 5. Hasil Uji Autokorelasi

\begin{tabular}{|r|c|r|r|}
\hline \multicolumn{4}{|c|}{ Model Summaryb } \\
\hline Model & $\mathrm{R}$ & R Square & Durbin-Watson \\
\hline 1 & $.673 \mathrm{a}$ & 453 & 967 \\
\hline
\end{tabular}

Uji Durbin Watson menunjukkan hasil dengan nilai DW 0,967. Jumlah observasi yang diperoleh (n) sebanyak 60, jumlah variabel bebas (k) 3, taraf signifikansi 0,05, dL = $1,4797, \mathrm{dU}=1,6889$. Karena DW 0,967 lebih rendah dari $\mathrm{dL}=1,4797$ dan lebih tinggi dari 0 maka tabel keputusan $\mathrm{H} 0$ ditolak (tidak ada autokorelasi positif pada tabel keadaan ini), yang berarti terdapat autokorelasi positif. 


\section{c. Uji Heteroskedastisitas}

Uji ini dilakukan dengan maksud untuk melakukan pengujian tentang ketidaksamaan varian residual yang ada dalam sebuah model regresi penelitian. Sebuah model regresi yang dikatakan baik jika tidak memiliki heteroskedastisitas (Ghozali, 2018).

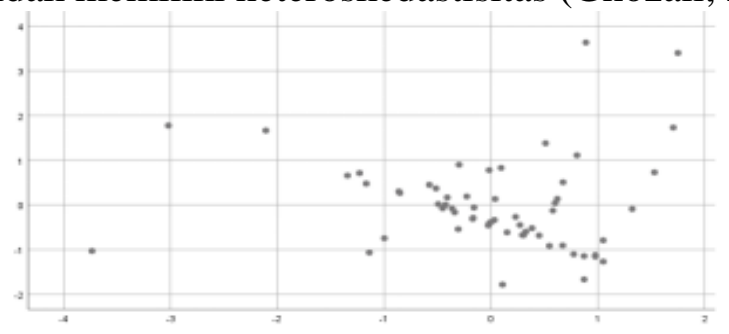

Gambar 4.1. Scatter Plot

Hasil scatter plot yang didapat terlihat bahwa titik-titik dalam plot tersebar secara random. Jadi dapat diambil kesimpulan bahwa tidak terdapat adanya heteroskedastisitas dalam model regresi, sehingga kesimpulan yang terjadi yaitu model regresi ini bisa digunakan untuk melakukan prediksi laba bersih berdasarkan variabel independen NPF, BOPO, dan FDR.

\section{d. Uji Normalitas}

Uji ini berguna untuk melakukan pengujian variabel residual yang ada apakah terdistribusi secara normal pada model regresi penelitian (Ghozali, 2018).

Tabel 6. Uji Normalitas

\begin{tabular}{|l|l|r|}
\hline \multicolumn{2}{|c|}{ One-Sample Kolmogorov-Smirnov Test } \\
\hline $\mathrm{N}$ & & Unstandardized Residual \\
\hline Normal Parametersa,b & Mean & 60 \\
\hline & & 41 \\
\hline & Std. Deviation & 25.672 .178 .795 .755 .100 .000 \\
\hline Most Extreme Differences & Absolute & 107 \\
\hline & Positive & 107 \\
\hline & Negative & -91 \\
\hline Test Statistic & & 107 \\
\hline Asymp. Sig. (2-tailed) & & $.084 c$ \\
\hline a Test distribution is Normal. & \\
\hline b Calculated from data. & \\
\hline c Lilliefors Significance Correction. & \\
\hline
\end{tabular}


Nilai yang diperoleh menurut tabel adalah 0,084 , nilai yang diperoleh $>$ nilai signifikansi 0,005 . Hal ini dapat berarti bahwa data yang terdapat dalam penelitian ini berdistribusi normal.

\section{KESIMPULAN}

Akhir dari penelitian ini didapat sebuah kesimpulan yaitu variabel bebas pada penelitian ini (NPF, BOPO, dan FDR) mempengaruhi variabel terikatnya (laba bersih) secara simultan. Lalu diantara variabel bebas, hanya NPF dan BOPO saja yang mempengaruhi variabel terikatnya (laba bersih) secara parsial. Variabel lainnya yaitu FDR tidak mempengaruhi secara parsial. Batasan yang terdapat pada penelitian ini yaitu hanya sebesar $45,3 \%$ saja pengaruh variabel bebas yang dapat dijabarkan terhadap variabel terikat dalam penelitian ini. Sisanya berasal dari variabel diluar variabel yang diteliti, dan semakin banyak variabel yang diteliti dapat diestimasi untuk melihat pengaruh variabel lain terhadap Laba Bersih.

\section{DAFTAR PUSTAKA}

AZIS, S. (2016). PENGARUH MAKRO EKONOMI DAN INTERNAL BANK SYARIAH TERHADAP LABA BERSIH BANK SYARIAH DI INDONESIA [STIE Perbanas Surabaya]. http://eprints.perbanas.ac.id/id/eprint/159

Bank Indonesia. (2011). Penerapan Manajemen Risiko bagi Bank Umum Syariah dan Unit Usaha Syariah. www.bi.go.id

Bank Indonesia. (2011). Surat Edaran No 13/24/DPNP Perihal Sistem Penilaian Tingkat Kesehatan Bank Umum.

Fatmawati, I. (2016). PENGARUH PEMBIAYAAN MURABAHAH, MUDHARABAH, MUSYARAKAH DAN IJARAH TERHADAP LABA BERSIH BANK UMUM SYARIAH DI INDONESIA [Universitas Jember]. http://repository.unej.ac.id/handle/123456789/75855

Ghozali, I. (2018). Aplikasi Analisis Multivariate dengan Program IBM SPSS 25 (Ninth Edit). Universitas Diponegoro.

Hasibuan, H. M. S. (2006). Dasar-dasar Perbankan (Fifth Edit). Bumi Aksara.

Ningsih, F. E. (2013). Analisis Perbandingan Beban Operasional dan Pendapatan Operasional (BOPO) pada PT Bank Muamalat Indonesia Tbk. Cabang Batam. JURNAL AKUNTANSI, EKONOMI DAN MANAJEMEN BISNIS, 1(2), 140146. https://doi.org/https://doi.org/10.30871/jaemb.v1i2.138

Nursya'adah, D. (2020). ANALISIS KEMAMPUAN PREDIKTIF LABA KOTOR, LABA OPERASI, LABA BERSIH, ARUS KAS OPERASI, PERUBAHAN HUTANG, PERUBAHAN PIUTANG, PERUBAHAN PERSEDIAAN DAN PERUBAHAN BEBAN DEPRESIASI TERHADAP ARUS KAS OPERASI MASA DEPAN. Prisma (Platform Riset Mahasiswa Akuntansi), 1(1), 120-135. https://ojs.stiesa.ac.id/index.php/prisma/article/view/373 
Otoritas Jasa Keuangan. (2016). Peraturan Otoritas Jasa Keuangan nomor 65/POJK. 03/2016 tentang Penerapan Manajemen Risiko bagi Bank Umum Syariah dan Unit Usaha Syariah.

Permataningayu, G., \& Mahdaria, S. (2019). The effect of non-performing financing and financing to deposit ratio on Islamic banks financing in Indonesia. Asian Journal of Islamic Management, 1(1), 28-37. https://doi.org/10.20885/ajim.vol1.iss1.art3

Purbaningsih, R. Y. P., \& Fatimah, N. (2018). THE EFFECT OF LIQUIDITY RISK AND NON PERFORMING FINANCING (NPF) RATIO TO COMMERCIAL SHARIA BANK PROFITABILITY IN INDONESIA. International Journal of Business, 16(1), 59-63. https://www.ijbel.com/wpcontent/uploads/2018/08/ACC-3.pdf

Rahman, T., \& Safitrie, D. (2018). PERAN NON PERFORMING FINANCING (NPF) DALAM HUBUNGAN ANTARA DEWAN KOMISARIS INDEPENDEN DAN PROFITABILITAS BANK SYARIAH. BISNIS : Jurnal Bisnis Dan Manajemen Islam, 6(1), 145-171. https://doi.org/http://dx.doi.org/10.21043/bisnis.v6i1.3701

Resha, D. A. (2017). ANALISIS PENGARUH FINANCING DEPOSITO RATIO (FDR), CAPITAL ADEQUACY RATIO (CAR), beban operasional TERHADAP PENDAPATAN OPERASIONAL (BOPO) DAN TOTAL ASET TERHADAP NON PERFORMING FINANCING (NPF)Studi Empiris pada Koperasi Jasa Keuangan Syariah (KJKS) Kota P [Universitas Andalas]. http://scholar.unand.ac.id/id/eprint/22534

Rispayanto, S. (2013). Pengaruh Laba Kotor, Laba Operasi, Laba Bersih Dan Arus Kas Operasi Dalam Memprediksi Arus Kas Operasi Masa Mendatang (Studi Empiris Pada Perusahaan Manufaktur yang Terdaftar di BEI). Jurnal Akuntansi, 1(3). http://ejournal.unp.ac.id/students/index.php/akt/article/view/673

Riyadi, S., \& Yulianto, A. (2014). Pengaruh Pembiayaan bagi Hasil, Pembiayaan Jual Beli, Financing to Deposit Ratio (FDR) dan Non Performing Financing (NPF) terhadap Profitabilitas Bank Umum Syariah di Indonesia. Accounting Analysis Journal, 3(4). https://doi.org/https://doi.org/10.15294/aaj.v3i4.4208

Rofi'ah, K., \& A'yun, A. (2019). Faktor-Faktor Non-Performing Financing (NPF) di Bank Umum Syariah Indonesia. Jurnal Ekonomi, 24(3), 452-467. https://doi.org/http://dx.doi.org/10.24912/je.v24i3.609

Suciah, A. (2017). Pengaruh Biaya operasional pada Pendapatan Operasional (BOPO), Financing To Deposit Ratio (FDR), Non Peforming Financing (NPF), dan Capital Adequacy Ratio (CAR) terhadap Return On Asset (ROA) pada Bank Umum Syariah Periode 2012-2016 [Universitas Islam Negeri Alauddin Makassar]. http://repositori.uin-alauddin.ac.id/id/eprint/8750 
SUHARTATIK, N. (2013). DETERMINAN FINANCING TO DEPOSIT RATIO PERBANKAN SYARIAH DI INDONESIA (2008-2012). Jurnal Ilmu Manajemen (JIM), 1(4). https://jurnalmahasiswa.unesa.ac.id/index.php/jim/article/view/6273

Sunhayati, Hidayat, A., \& Dayono, B. T. (2020). KAJIAN INTENSI NPL (NET PERFORMING LOAN) DAN NIM (NET INTEREST MARGIN) TERHADAP LABA BERSIH. Jurnal Revenue : Jurnal Ilmiah Akuntansi, 1(2), 254-259. https://doi.org/https://doi.org/10.46306/rev.v1i2.31

Supeno, W. (2019). Analisis Efisiensi Bopo Terhadap Laba Bersih Pada BPR. Jurnal Kajian Ilmiah, 19(2), 182-194. https://doi.org/http://dx.doi.org/10.31599/jki.v19i2.460

Suryani, S. (2011). ANALISIS PENGARUH FINANCING TO DEPOSIT RATIO (FDR) TERHADAP PROFITABILITAS PERBANKAN SYARIAH DI INDONESIA. Walisongo: Jurnal Penelitian Sosial Keagamaan, 19(1), 47-74. https://doi.org/10.21580/ws.19.1.212

Tasriani, T. (2015). Penerapan Dan Pengelolaan Manajemen Resiko (Risk) Dalam Industri Perbankan Syariah: Studi Pada Bank BUMN dan Bank Non BUMN. Sosial Budaya, $12(1)$, 80-101. https://doi.org/http://dx.doi.org/10.24014/sb.v12i1.1933

WARDIANTIKA, L. (2014). PENGARUH DPK, CAR, NPF, DAN SWBI TERHADAP PEMBIAYAAN MURABAHAH PADA BANK UMUM SYARIAH TAHUN 2008-2012. Jurnal Ilmu Manajemen (JIM), 2(4). https://jurnalmahasiswa.unesa.ac.id/index.php/jim/article/view/11151 